\title{
ANALISIS KONDISI LAMUN (SEAGRASS) DI PERAIRAN PULAU PRAMUKA, KEPULAUAN SERIBU
}

\author{
Septi Dwi Fajarwati ${ }^{1}$, Asma Irma Setianingsih ${ }^{2}$, Muzani ${ }^{2}$ \\ ${ }^{1}$ Mahasiswa Jurusan Geografi FIS UNJ \\ 2Dosen Jurusan Geografi FIS UNJ \\ E-mail: Muzaniunj@yahoo.com
}

\begin{abstract}
This research aims to analyze the condition of seagrass ecosystem to see water quality data of the seagrass habitat and percentage cover of seagrass in the waters of the Pramuka Island, Seribu Islands. The research was conducted over two months from October to November 2014. This research used a descriptive method with field survey approach. The population in this study is the seagrass in Waters Pramuka Island. Determining the location with purposive sampling of the sampling is divided into three stations is North, East and South. Data collection techniques include primary data and secondary data. Primary data is data of seagrass (type, percentage cover and density of seagrass) and data of seagrass habitat environmental parameters (water temperature, current speed, brightness, depth, salinity, substrate, TSS, DO, pH) were obtained by direct measurement in the field, while secondary data include the general state of the research sites. Data analysis techniques used in this study using analysis of community structure of seagrass and water quality analysis.

The results showed that seagrass species found in the Pramuka Island there are 6 types of seagrass Cymodocea rotundata, Cymodocea serrulata, Enhalus acoroides, Halophila ovalis, Halodule uninervis, Thalassia hemprichii. Conditions of seagrass in the waters of the Pramuka Island included into the category of less healthy-poor seagrass. At station 1 percentage by $31 \%$ classified seagrass less healthy conditions, while the other two stations are stations 2 and 3 belong to the category of the poor condition of seagrass, with each percentage cover of seagrass $19.4 \%$ and $20.3 \%$. Of all water quality parameters measured, all the parameters are still in normal circumstances, but there are some parameters whose value is high at some stations TSS and $\mathrm{pH}$ value is high at station 2 with a value of TSS $18 \mathrm{mg} / \mathrm{l}$ and a pH value of 8.2. Water quality and seagrass communities in station 1 is still in good condition for the growth of seagrass, because at this station is an unspoiled area away from human activity, while the stations 2 and 3 have undergone changes in community structure of seagrass because at this station has several anthropogenic activities that disrupt the lives of seagrass, mostly from human activities such as domestic sewage and hoarding/reclamation, which affects the condition of seagrass at station 2 and 3 are poor seagrass.
\end{abstract}

Keyword: Seagrass, Water Quality, Pramuka Island

\section{PENDAHULUAN}

Lamun atau secara internasional dikenal sebagai seagrass, merupakan tumbuhan tingkat tinggi dan berbunga (Angiospermae) yang sudah sepenuhnya menyesuaikan diri hidup terbenam di dalam laut dangkal. Lamun tidak sama dengan rumput laut. Rumput laut yang sering disebut oleh masyarakat umum, sebenarnya adalah makroalga, sedangkan tumbuhan lamun yang telah disebutkan di atas, tergolong Angiospermae.
Ekosistem lamun memiliki berbagai fungsi penting di laut dangkal ini belum banyak dikenal dan diperhatikan bila dibandingkan dengan ekosistem pesisir lainnya seperti mangrove dan terumbu karang. Tomascik et al. (1997) menyatakan bahwa ekosistem padang lamun di daerah pesisir memiliki fungsi sebagai produsen primer, pendaur zat hara, stabilisator dasar perairan, perangkap sedimen, serta penahan erosi bagi kehidupan ikan sebagai tempat berlindung, tempat mencari makan dan sebagai ruang hidup. Fungsi lain dari lamun 
yang sangat penting bagi kehidupan di bumi yaitu lamun berfungsi sebagai penyerab karbon, yang kurang lebih sama dengan kemampuan seluruh tumbuhan di darat dalam menyerap $\mathrm{CO}_{2}$ dari atmosfer (Nontji, 2010).

Sebagai ekosistem pesisir, keberadaan ekosistem lamun ini memiliki ancaman kerusakan yang dapat mengurangi jumlah populasinya. Kerusakan ekosistem lamun disebabkan dari kegiatan manusia dan juga dari aktivitas alam.

Sumberdaya lamun yang berada di perairan dangkal Pulau Pramuka, Kepulauan
Seribu memiliki potensi yang cukup baik, namun beberapa waktu belakangan ini sumberdaya lamun di perairan tersebut telah mengalami degradasi sehingga kelestarian sumberdaya lamun dan biota yang berasosiasi dengan sumberdaya tersebut juga terganggu. Kondisi lamun di perairan Pulau Pramuka mengalami penurunan persentase penutupan lamun dari tahun 2009, 2011 dan 2012. Berikut ini persentase penutupan lamun di Pulau Pramuka berdasarkan hasil dari penelitian terdahulu.

Tabel 1. Persentase penutupan lamun di Pulau Pramuka

\begin{tabular}{cccc}
\hline & \multicolumn{3}{c}{ Penutupan Lamun (\%) } \\
\cline { 2 - 4 } Tahun & $\begin{array}{c}\text { Stasiun 1 } \\
\text { (Utara) }\end{array}$ & $\begin{array}{c}\text { Stasiun 2 } \\
\text { (Timur) }\end{array}$ & $\begin{array}{c}\text { Stasiun 3 } \\
\text { (Selatan) }\end{array}$ \\
\hline 2009 & 68 & 59 & 48 \\
2011 & 30,7 & 26,2 & 37 \\
2012 & 31,3 & 23,2 & 19,6 \\
\hline
\end{tabular}

Sumber: Balai Taman Nasional Kepulauan Seribu (2012)

Berdasarkan tabel di atas, pada tahun 2009 ke tahun 2011 terjadi penurunan persentase tutupan lamun di ketiga stasiun pengamatan lamun di Pulau Pramuka. Ketiga stasiun tersebut menunjukkan angka penurunan yang cukup drastis, pada stasiun 1 yang letaknya berada di Utara Pulau Pramuka mengalami penurunan sebesar $54 \%$, stasiun 2 yang berada di sebelah Timur mengalami penurunan sebesar $56 \%$, sedangkan stasiun 3 yang berada di sebelah Selatan juga mengalami penurunan sebesar $23 \%$.

Selain itu, pada tahun 2011 ke tahun 2012 juga masih terdapat penurunan persentase tutupan lamun yang terjadi pada stasiun 2 dan stasiun 3 yang berada di sebelah Timur dan Selatan Pulau Pramuka dengan persentase penurunan masing-masing sebesar $11 \%$ dan $47 \%$, sedangkan yang terjadi pada stasiun 1 mengalami kenaikan, namun hanya sebesar $2 \%$. Dari data di atas, terlihat adanya tingkat penurunan penutupan lamun yang terjadi pada ekosistem lamun di perairan Pulau Pramuka yang dapat mengancam kelangsungan hidup dari lamun tersebut.
Pulau Pramuka sebagai pusat pemerintahan merupakan pulau pemukiman dengan kepadatan penduduk yang cukup tinggi, dan juga daerah tujuan wisata yang banyak dikunjungi wisatawan sehingga aktivitas dari penduduk setempat maupun wisatawan dapat memberikan dampak terhadap ekosistem pesisir khususnya ekosistem lamun yang hidupnya di perairan laut dangkal dekat dengan daratan di mana tempat manusia beraktivitas. Berkembangnya kegiatan manusia di wilayah pesisir khususnya di perairan Pulau Pramuka seperti kegiatan pariwisata, pemukiman dan aktivitas lainnya memungkinkan adanya pengaruh terhadap ekosistem lamun, sehingga diduga mengalami perubahan fisik, kelimpahan maupun sebarannya.

Dikhawatirkan hilangnya padang lamun ini akan terus meningkat akibat berkembangnya kegiatan manusia di daerah pesisir. Bila aktivitas manusia ini meningkat maka kualitas lingkungan perairan akan menurun dan juga akan menurunkan fungsi dari ekosistem lamun tersebut. Oleh karena itu, perlu dilakukan kajian mengenai kondisi ekosistem lamun, dilihat dari 
kualitas perairannya serta komunitas lamun di perairan tersebut, sehingga mendapat gambaran lebih lengkap tentang kondisi lamun di Pulau Pramuka agar kelestarian dari ekosistem ini dapat terjaga.

\section{METODOLOGI PENELITIAN}

Tujuan penelitian ini adalah untuk menganalisis kondisi ekosistem lamun (seagrass) dengan melihat data kualitas perairan pada habitat lamun serta persentase penutupan lamun di Perairan Pulau Pramuka, Kepulauan Seribu. Lokasi penelitian ini yaitu lamun di Perairan Pulau Pramuka, Kepulauan Seribu Utara. Waktu penelitian dilaksanakan selama 2 bulan terhitung mulai bulan Oktober sampai bulan November 2014. Metode yang digunakan dalam penelitian ini adalah metode deskriptif dengan pendekatan survey lapangan.

Populasi dalam penelitian ini adalah lamun yang ada di Perairan Pulau Pramuka, Kepulauan Seribu. Penentuan lokasi sampling dibagi menjadi tiga stasiun dimana setiap stasiun dibagi lagi menjadi tiga substasiun, pengambilan sampel dengan purposive sampling, berdasarkan pada perbedaan karakteristik lokasi tiap stasiun yaitu sebelah Utara, Timur dan Selatan. Stasiun 1 berada di sebelah Utara yang letaknya jauh dari pemukiman penduduk dan jauh dari aktivitas masyarakat. Stasiun 2 berada di sebelah Timur yang letaknya berada di dekat pemukiman penduduk sedangkan stasiun 3 berada di dekat pemukiman penduduk dan resort wisatawan.

Teknik pengumpulan data yang digunakan adalah data primer yaitu data lamun dan data kualitas perairan habitat lamun. Data lamun yang diukur meliputi jenis lamun, kerapatan lamun dan persentase penutupan lamun. Pengamatan terhadap lamun menggunakan metode "Kuadrat Transect". Di setiap stasiun pengamatan diletakan transek-transek garis dari arah darat ke arah laut, seperti pada Gambar 1. Alat-alat yang digunakan yaitu transek kuadrat yang berukuran $50 \times 50 \mathrm{~cm}$, kamera digital, rollmeter, GPS dan alat dasar selam.

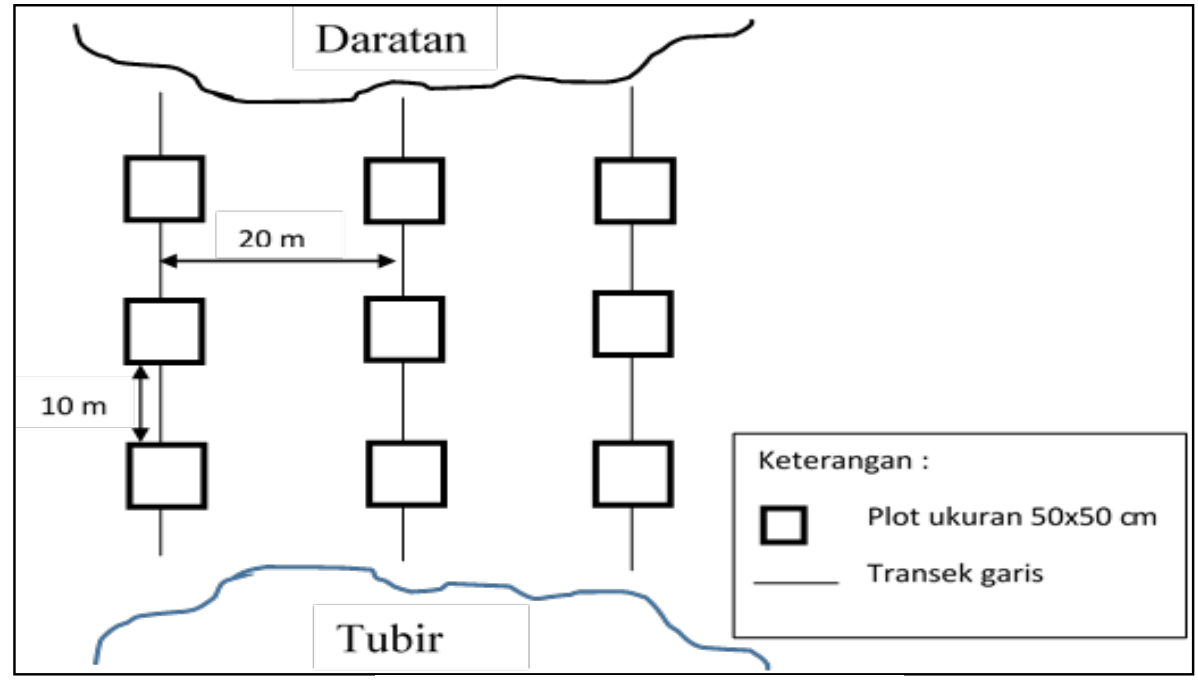

Gambar 1. Plot pengamatan lamun

Selain data lamun, data primer lainnya yaitu data kualitas perairan habitat lamun parameter fisika antara lain: suhu air, kecepatan arus, kecerahan, kedalaman, salinitas, substrat dan TSS, parameter kimia antara lain: salinitas, DO dan $\mathrm{pH}$ yang diperoleh dengan melakukan pengukuran langsung di lapangan, untuk parameter TSS dan substrat diambil sampelnya di lapangan selanjutnya dilakukan analisis di Laboratorium Produktivitas Lingkungan FPIK IPB. Data primer lainnya yaitu untuk mengetahui aktivitas antropogenik yang terdapat di lokasi penelitian, maka dilakukan observasi dan wawancara. 
Data sekunder meliputi keadaan umum lokasi penelitian. Teknik analisis data yang digunakan dalam penelitian ini menggunakan analisis struktur komunitas lamun dan analisis kualitas perairan disajikan secara deskriptif.

\section{HASIL DAN PEMBAHASAN Kualitas Perairan Habitat Lamun}

Kondisi lingkungan perairan dapat dilihat dari parameter fisika dan kimia perairan juga akan mempengaruhi struktur komunitas biota yang hidup di dalamnya, yaitu komunitas lamun. Berikut ini adalah hasil pengukuran parameter fisika dan kimia pada habitat lamun di perairan Pulau Pramuka.

Tabel 2. Parameter Kualitas Perairan

\begin{tabular}{|c|c|c|c|c|c|}
\hline \multirow{2}{*}{ No. } & \multirow{2}{*}{$\begin{array}{c}\text { Parameter Kualitas } \\
\text { Perairan }\end{array}$} & \multirow{2}{*}{ Baku mutu } & \multicolumn{3}{|c|}{ Stasiun pengamatan } \\
\hline & & & Stasiun 1 & Stasiun 2 & Stasiun 3 \\
\hline \multicolumn{6}{|c|}{ Parameter Fisika } \\
\hline 1. & Suhu $\left({ }^{\circ} \mathrm{C}\right)$ & $28-30$ & 30 & 29 & 33 \\
\hline 2. & Kedalaman (m) & - & $0,9-1,35$ & $0,85-1$ & $0,7-0,89$ \\
\hline 3. & Kecerahan (\%) & - & 100 & 100 & 100 \\
\hline 4. & Kecepatan arus (m/s) & - & 0,54 & 0,62 & 0,48 \\
\hline 5. & TSS (mg/l) & 20 & 5 & 18 & 12 \\
\hline \multicolumn{6}{|c|}{ Parameter Kimia } \\
\hline 1. & $\mathrm{pH}$ & $7,0-8,5$ & 7,9 & 8,2 & 8,0 \\
\hline 2. & $\mathrm{DO}(\mathrm{mg} / \mathrm{l})$ & $>5$ & 7,1 & 6,0 & 6,2 \\
\hline 3. & Salinitas $(\% 0)$ & $33-34$ & 33 & 27 & 29 \\
\hline
\end{tabular}

Sumber: Hasil Penelitian, November 2014

Berdasarkan tabel di atas, suhu air yang terukur pada Perairan Pulau Pramuka berada pada kisaran $29-33^{\circ} \mathrm{C}$. Suhu perairan terendah di stasiun 2 sebesar $29^{\circ} \mathrm{C}$, di mana pada saat pengukuran dilakukan pada pagi hari, sedangkan pada stasiun 3 suhu airnya mencapai $33^{\circ} \mathrm{C}$ pengukuran dilakukan pada siang hari dan cuaca saat itu panas. suhu optimal untuk pertumbuhan lamun berkisar antara $28-30^{\circ} \mathrm{C}$, sedangkan stasiun 3 melebihi suhu optimal untuk pertumbuhan lamun. Suhu yang tinggi pada penelitian mengakibatkan banyaknya daun lamun yang hilang dan menaikkan suhu sedimen.

Kedalaman yang terukur di 3 stasiun penelitian berkisar antara 0,7-1,35 meter, di mana kedalaman berbeda-beda di tiap stasiun. Kondisi perairan yang dangkal mempengaruhi kehidupan lamun, karena perubahan kedalaman air dapat mempengaruhi beberapa faktor lingkungan perairan yang lain, yaitu suhu, intensitas cahaya dan hidrodinamika air.

Kecerahan pada Perairan Pulau Pramuka yang terukur adalah $100 \%$ ini berarti bahwa pada lokasi penelitian penyinaran terjadi hingga ke dasar perairan. Kecepatan arus yang terukur pada ketiga lokasi penelitian berkisar pada 0,48-0,62 $\mathrm{m} / \mathrm{s}$ dengan rata-rata kecepatan arusnya sebesar $0,55 \mathrm{~m} / \mathrm{s}$. Kecepatan arus relatif tenang, hal ini dipengaruhi oleh angin, selain itu dangkalnya perairan dan keberadaan lamun di tiap lokasi yang berpengaruh cukup besar dalam memperlambat pergerakan arus.

Total Suspended Solid (TSS) yang berada di setiap stasiun penelitian berbeda-beda, pada stasiun 1 sebesar $5 \mathrm{mg} / \mathrm{l}$, pada stasiun 2 sebesar $18 \mathrm{mg} / \mathrm{l}$ dan stasiun 3 sebesar $12 \mathrm{mg} / \mathrm{l}$. Nilai TSS yang terukur pada setiap stasiun pengamatan berbeda berkisar antara $5-18 \mathrm{mg} / \mathrm{l}$. Tingginya perbedaan nilai TSS antara stasiun mengindikasikan bahwa Perairan Pulau 
Pramuka terjadi sedimentasi atau proses pengendapan tinggi di beberapa stasiun pengamatan.

Nilai derajat keasaman $(\mathrm{pH})$ yang terukur di lokasi pengamatan berkisar antara 7,9-8,2. Nilai $\mathrm{pH}$ tertinggi terdapat di stasiun 2 yaitu sebesar 8,2 ini berarti perairan di lokasi ini bersifat basa, dan di stasiun lainnya juga cenderung bersifat basa.

Kadar oksigen terlarut (disolved oxygen) yang diperoleh dari hasil pengukuran di lokasi pengamatan yaitu pada stasiun 1 sebesar 7,1 $\mathrm{mg} / \mathrm{l}$ dan di stasiun 2 sebesar $6,0 \mathrm{mg} / \mathrm{l}$, stasiun 3 sebesar 6,2 mg/l. Kadar DO yang normal untuk biota laut yaitu sebesar $>5 \mathrm{mg} / \mathrm{l}$ ini berarti bahwa kadar oksigen terlarut di Perairan Pulau Pramuka menunjukan kondisi yang baik karena masih sesuai dengan baku mutu untuk biota laut.

Salinitas atau kadar garam yang terukur di lokasi pengamatan berkisar $27-33 \%$, di mana setiap lokasi berbeda salinitasnya. Pada stasiun 1 nilai salinitasnya tinggi yaitu sebesar $33 \%$ dan nilai salinitas terendah terdapat di stasiun 2 yaitu sebesar $27 \%$. Nilai salinitas yang dapat ditoleransi oleh lamun bervariasi di antara setiap jenisnya, sehingga dapat mempengaruhi sebaran jenis lamun yang terdapat di Perairan Pulau Pramuka.

Substrat merupakan media tumbuhnya lamun yang memegang peranan distribusi lamun mulai dari garis pantai pada saat surut terendah. Karakteristik substrat pada Tabel 3.

Tabel 3. Karakteristik substrat

\begin{tabular}{lccc}
\hline \multicolumn{1}{c}{ Tipe Substrat } & Stasiun 1 & Stasiun 2 & Stasiun 3 \\
\hline Gravel (butiran batu /pecahan karang) & $6,75 \%$ & $0,36 \%$ & $7,54 \%$ \\
Sand (pasir) & $77,79 \%$ & $76,58 \%$ & $77,67 \%$ \\
Silt (lumpur) & $15,54 \%$ & $23,07 \%$ & $14,78 \%$ \\
\hline Sumber: Hasil Penelitian, November 2014 & &
\end{tabular}

Tipe substrat ketiga stasiun didominasi oleh substrat pasir yang butirannya kasar dengan rata-rata persentase $77,34 \%$ sisanya ditemukan substrat lumpur dan sebagian kecil substrat gravel. Pada beberapa substasiun yang mendekati tubir, substrat yang ditemukan yaitu gravel (butiran batu dan pecahan karang) maka dari persentase komposisi substrat di atas komposisi gravel paling sedikit persentasenya karena hanya ditemukan pada substasiun yang dekat dengan tubir. Peranan kedalaman substrat dalam stabilitas sedimen mencakup 2 hal, yaitu pelindung tanaman dari arus laut dan tempat pengolahan dan pemasok nutrien.

\section{Struktur Komunitas Lamun a.Jenis-jenis Lamun}

Tabel 4. Jenis-jenis lamun yang ditemukan di masing-masing stasiun

\begin{tabular}{clccc}
\hline No. & Jenis lamun & Stasiun 1 & Stasiun 2 & Stasiun 3 \\
\hline 1. & Cymodocea rotundata & $\sqrt{ }$ & $\sqrt{ }$ & $\sqrt{ }$ \\
2. & Cymodocea serrulata & $\sqrt{ }$ & $\sqrt{ }$ & $\sqrt{ }$ \\
3. & Enhalus acoroides & $\sqrt{ }$ & $\sqrt{ }$ & - \\
4. & Halodule uninervis & $\sqrt{ }$ & - & $\sqrt{ }$ \\
5. & Halophila ovalis & $\sqrt{ }$ & - & - \\
6. & Thalassia hemprichii & $\sqrt{ }$ & $\sqrt{ }$ & $\sqrt{ }$ \\
\hline
\end{tabular}

Sumber: Hasil Penelitian, November 2014

Berdasarkan hasil pengamatan, diketahui bahwa di Pulau Pramuka ditemukan sebanyak 6 jenis lamun yang tersebar di tiga lokasi pengamatan. Jenis lamun yang mendominasi dan tersebar merata di setiap stasiun yaitu, 
Cymodocea rotundata, Cymodocea serrulata

Stasiun 1

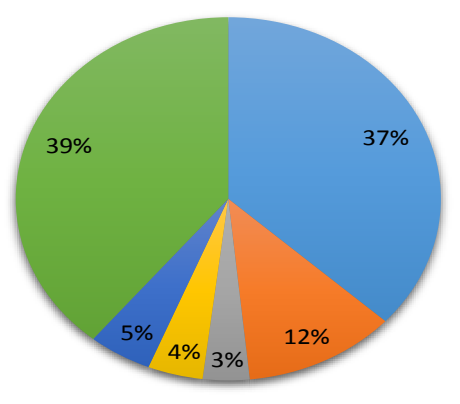

- Cymodocea rotundata $\square$ Cymodocea serrulata

Enhalus acoroides Halodule uninervis

- Halophila ovalis $\quad$ Thalassia hemprichii dan Thalassia hemprichii.

Stasiun 2

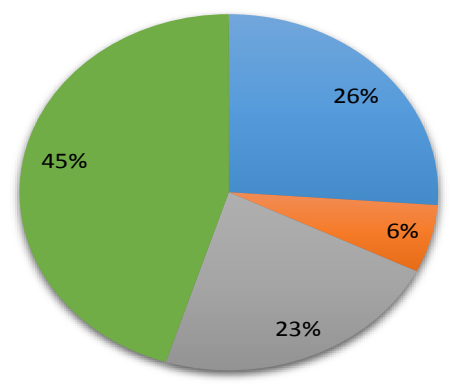

- Cymodocea rotundata 1 Cymodocea serrulata

Enhalus acoroides $\quad$ Thalassia hemprichii

\section{Stasiun 3}

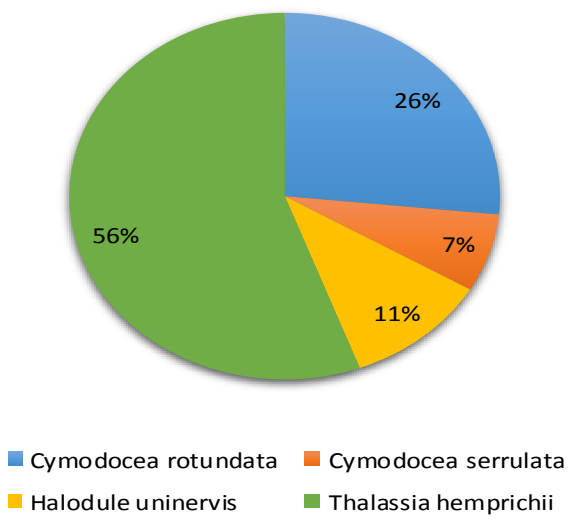

\section{Gambar 2. Komposisi jenis lamun di tiap-tiap stasiun penelitian}

Pada stasiun 1 ditemukan 6 jenis lamun, sedangkan di stasiun 2 yang berada di sebelah Timur dan stasiun 3 yang berada di sebelah Selatan hanya ditemukan 4 jenis lamun. Besarnya komposisi jenis lamun pada masingmasing stasiun dapat dilihat pada Gambar 2 di atas. Berdasarkan Gambar 2, jenis lamun Thalassia hemprichii memiliki komposisi terbesar di ketiga stasiun penelitian. Jenis lamun yang paling rendah komposisinya yaitu Halophila ovalis karena jenis lamun ini hanya terdapat pada stasiun 1 , sedangkan di stasiun 2 dan 3 tidak terdapat jenis tersebut.
Pada stasiun 1 ditemukan 6 jenis lamun dengan komposisi tertinggi adalah jenis lamun Thalassia hemprichii mencapai $39 \%$ dan komposisi terendah adalah jenis lamun Enhalus acoroides dengan persentase 3\%. Banyaknya jenis lamun yang ditemukan di stasiun ini disebabkan stasiun ini masih dalam kondisi alami dan ideal untuh tumbuh berbagai jenis lamun.

Pada stasiun 2 ditemukan 4 jenis lamun dengan komposisi tertinggi ada pada jenis lamun Thalassia hemprichii dengan persentasi mencapai $45 \%$ sedangkan yang terendah adalah jenis lamun Cymodocea serrulata 6\%. 
Pada stasiun ini tidak ditemukan jenis lamun Halodule uninervis dan Halophila ovalis diduga habitat pada stasiun 2 tidak cocok untuk tumbuhnya kedua jenis lamun tersebut.

Berdasarkan hasil pengamatan, jenis lamun Thalassia hemprichii mendominasi di ketiga stasiun pengamatan, hal ini diduga pada lokasi penelitian memiliki karakteristik substrat dan faktor lingkungan yang cocok untuk pertumbuhan lamun jenis ini. Thalassia merupakan salah satu spesies lamun yang mempunyai daya toleransi yang sangat luas terhadap salinitas, lamun jenis tersebut dapat tumbuh optimum pada kisaran salinitas 24-
$35 \%$, namun dapat juga ditemukan hidup pada salinitas 3,5 - 60\%o (Dahuri, 2003).

Jenis Halophila ovalis hanya ditemukan di stasiun 1, sedangkan stasiun 2 dan 3 tidak ditemukan diduga karena lamun jenis ini memiliki morfologi yang lebih kecil dibandingkan dengan jenis lamun lainnya dan lamun jenis ini sensitif terhadap perubahan lingkungan.

\section{Kerapatan Lamun}

Kerapatan lamun adalah banyaknya jumlah individu atau tegakan suatu spesies lamun pada luasan tertentu. Kerapatan jenis lamun di Pulau Pramuka pada setiap stasiun dapat dilihat pada Tabel 5.

Tabel 5. Kerapatan jenis lamun (ind $/ \mathrm{m}^{2}$ )

\begin{tabular}{ccccc}
\hline \multirow{2}{*}{ No. } & Jenis lamun & \multicolumn{3}{c}{ Kerapatan $\left(\mathrm{ind} / \mathrm{m}^{2}\right)$} \\
\cline { 3 - 5 } & & Stasiun 1 & Stasiun 2 & Stasiun 3 \\
\hline 1. & Cymodocea rotundata & 304 & 101,3 & 214,6 \\
2. & Cymodocea serrulata & 113,3 & 32 & 77,3 \\
3. & Enhalus acoroides & 58,7 & 93,3 & 0 \\
4. & Halodule uninervis & 69,3 & 0 & 90,7 \\
5. & Halophila ovalis & 86,7 & 0 & 0 \\
6. & Thalassia hemprichii & 302,7 & 144 & 310,7 \\
& Total & 934,7 & 370,6 & 693,3 \\
\hline
\end{tabular}

Sumber: Hasil Penelitian, November 2014

Pada Tabel 5, menunjukkan kerapatan jenis lamun pada tiap stasiun, berdasarkan hasil pengamatan dapat diketahui bahwa kerapatan jenis lamun berbeda pada setiap stasiun pengamatan. Kerapatan jenis tertinggi di ketiga stasiun yaitu Thalassia hemprichii, hal ini disebabkan jenis substrat pada lokasi penelitian yang memiliki ukuran sedimen yang lebih besar sangat cocok bagi Thalassia hemprichii. Faktor lingkungan juga mempengaruhi besarnya kerapatan lamun jenis ini meliputi kedalaman, intensitas cahaya dan salinitas. Kedalaman pada lokasi penelitian sekitar 0,7-1,35 meter dan berada pada daerah interdal, kedalaman ini sesuai dengan pertumbuhan jenis lamun Thalassia hemprichii.

Kerapatan jenis terendah yaitu terdapat pada lamun jenis Halophila ovalis, hal ini disebabkan jenis lamun Halophila ovalis memiliki morfologi yang sangat kecil dan biasanya tertutup oleh sedimen sehingga sulit diamati jika kadar sedimen tinggi akan menghambat pertumbuhan lamun ini, lamun jenis ini sensitif terhadap perubahan lingkungan. Jadi, lamun ini sulit ditemukan pada daerah yang sudah tercemar apalagi tertutup oleh sedimen yang berasal dari limbah masyarakat.

Jumlah total individu lamun pada stasiun 1 , 2 dan 3 yaitu $934,7 \mathrm{ind} / \mathrm{m}^{2}, 370,6 \mathrm{ind} / \mathrm{m}^{2}$ dan $693,3 \mathrm{ind} / \mathrm{m} 2$. Kerapatan jenis lamun tertinggi terdapat pada stasiun 1 di sebelah Utara yang mencapai $934,7 \mathrm{ind} / \mathrm{m}^{2}$ dan kerapatan jenis lamun terendah terdapat pada stasiun 2 yang berada di sebelah Timur. Hal ini sesuai dengan pernyataan Kiswara, 2004 bahwa lamun 
tumbuh pada daerah yang lebih dalam dan jernih memiliki kerapatan jenis lebih tinggi dari pada lamun yang tumbuh di daerah dangkal dan keruh. Stasiun 1 memiliki kerapatan lamun tertinggi, karena diantara ketiga stasiun penelitian, stasiun 1 merupakan perairan yang lebih dalam dan jernih dibandingkan dua stasiun lainnya (Tabel 1).

Persentase Penutupan Lamun
Penutupan lamun menggambarkan seberapa luas lamun yang menutupi suatu perairan dan biasanya dinyatakan dalam persen. Nilai persen penutupan tidak hanya bergantung pada nilai kerapatan jenis lamun, melainkan dipengaruhi juga oleh keadaan morfologi dari jenis lamun tersebut. Persentase penutupan lamun tiap stasiun pengamatan bisa dilihat pada Tabel 6 .

Tabel 6. Persentase penutupan lamun (\%)

\begin{tabular}{ccccc}
\hline \multirow{2}{*}{ No. } & Jenis lamun & \multicolumn{3}{c}{ Persentase (\%) } \\
\cline { 3 - 5 } & & Stasiun 1 & Stasiun 2 & Stasiun 3 \\
\hline 1. & Cymodocea rotundata & 11,4 & 5,1 & 5,4 \\
2. & Cymodocea serrulata & 3,6 & 1,2 & 1,4 \\
3. & Enhalus acoroides & 1,1 & 4,4 & 0 \\
4. & Halodule uninervis & 1,3 & 0 & 2,2 \\
5. & Halophila ovalis & 1,5 & 0 & 0 \\
6. & Thalassia hemprichii & 12,1 & 8,8 & 11,3 \\
& Total & 31 & 19,4 & 20,3 \\
\hline
\end{tabular}

Sumber: Hasil Penelitian, November 2014

Dari Tabel di atas, dapat dilihat persentase tutupan lamun terbesar terdapat pada stasiun 1 yang terletak di sebelah Utara Pulau Pramuka dengan tutupan sebesar 31\%, selanjutnya tutupan lamun stasiun 3 di sebelah Selatan dengan tutupan sebesar 20,3\%, dan yang terendah pada stasiun 2 yang berada di sebelah Timur dengan tutupan sebesar $19,4 \%$.

Persentase penutupan lamun ini menjadi indikator dalam menentukan kondisi komunitas lamun di suatu wilayah.Berdasarkan Keputusan Menteri Negara Lingkungan Hidup No. 200 tahun 2004, kategori lamun dibagi menjadi 3 kategori, yaitu kondisi lamun sehat/kaya persentase penutupan lamunnya $\geq 60 \%$, lamun kurang sehat/kurang kaya 30-59,9\% penutupannya dan miskin lamun dengan persentase $\leq 29,9 \%$.

Hasil penelitian di lapangan menunjukkan bahwa, persentase penutupan lamun di Pulau Pramuka termasuk kedalam kategori kurang sehat dan miskin lamun. Pada stasiun 1 persentase lamun sebesar $31 \%$ tergolong kondisi lamun yang kurang sehat, sedangkan dua stasiun lainnya yaitu stasiun 2 dan 3 termasuk ke dalam kategori kondisi miskin lamun, dengan masing-masing persentase penutupan lamun sebesar $19,4 \%$ dan $20,3 \%$. Jika hasil penelitian persentase penutupan lamun pada tahun 2014 dibandingkan dengan data sekunder pada tahun 2012, maka akan terlihat seperti pada Tabel 7 berikut ini.

Tabel 7. Persentase penutupan lamun pada tahun 2012 dan 2014

\begin{tabular}{cccc}
\hline \multirow{2}{*}{ Tahun } & \multicolumn{3}{c}{ Persentase penutupan lamun (\%) } \\
\cline { 2 - 4 } & $\begin{array}{c}\text { Stasiun 1 } \\
\text { (Utara) }\end{array}$ & $\begin{array}{c}\text { Stasiun 2 } \\
\text { (Timur) }\end{array}$ & $\begin{array}{c}\text { Stasiun 3 } \\
\text { (Selatan) }\end{array}$ \\
\hline 2012 & 31,3 & 23,2 & 19,6 \\
2014 & 31 & 19,4 & 20,3
\end{tabular}

Sumber: Balai Taman Nasional Kepulauan Seribu, 2012; Hasil Penelitian, November 2014

Berdasarkan tabel di atas, pada tahun 2012 ke tahun 2014 terdapat penurunan persentase tutupan lamun yang terjadi pada stasiun 1 dan stasiun 2 yang berada di sebelah 
Utara dan Timur Pulau Pramuka. Pada stasiun 1 mengalami penurunan persentase penutupan lamun sebesar $1 \%$, pada stasiun 2 juga mengalami penurunan sebesar 16\%, sedangkan yang terjadi pada stasiun 3 mengalami kenaikan, namun hanya sebesar $3 \%$. Jadi, dari ketiga stasiun pengamatan tersebut, ternyata stasiun 2 yang mengalami penurunan persentase tutupan lamun paling besar dibandingkan dengan stasiun pengamatan lainnya. Hal ini diduga berkurangnya persentase penutupan lamun pada stasiun 2 diikuti juga dengan penurunan kualitas perairannya.

Berdasarkan hasil penelitian, jenis-jenis antropogenik yang terjadi di setiap stasiun antara stasiun yang berada di Utara, Timur dan Selatan berbeda-beda seperti yang ditampilkan pada Tabel 8 di bawah ini.

Tabel 8. Jenis antropogenik yang ditemukan di lokasi penelitian

\begin{tabular}{|c|c|c|c|c|c|}
\hline No. & Jenis antropogenik & Stasiun 1 & Stasiun 2 & Stasiun 3 & Dampak terhadap lamun \\
\hline \multirow[t]{3}{*}{1.} & $\begin{array}{l}\text { Limbah domestik: } \\
\text { - Jenis limbah yang } \\
\text { ditemukan }\end{array}$ & $\begin{array}{l}\text { Limbah } \\
\text { padat }\end{array}$ & $\begin{array}{l}\text { Limbah } \\
\text { padat dan } \\
\text { cair }\end{array}$ & $\begin{array}{l}\text { Limbah } \\
\text { padat dan } \\
\text { cair }\end{array}$ & $\begin{array}{l}\text { Meningkatnya kadar TSS dan pH } \\
\text { pada perairan yang banyak } \\
\text { ditemukan limbah domestik, } \\
\text { sehingga tertutupnya lamun oleh }\end{array}$ \\
\hline & $\begin{array}{l}\text { - Tempat } \\
\text { pembuangan } \\
\text { sampah }\end{array}$ & Tidak ada & Ada & Tidak ada & $\begin{array}{l}\text { sampah dan mengurangi intensitas } \\
\text { cahaya yang diterima lamun. }\end{array}$ \\
\hline & $\begin{array}{l}\text { - Saluran limbah } \\
\text { cair }\end{array}$ & Tidak ada & $\begin{array}{l}\text { Ada } 2 \\
\text { saluran }\end{array}$ & $\begin{array}{l}\text { Ada } 1 \\
\text { saluran }\end{array}$ & \\
\hline 2. & $\begin{array}{l}\text { Penimbunan/ } \\
\text { reklamasi pantai }\end{array}$ & Tidak ada & Ada & Ada & $\begin{array}{l}\text { Menghilangkan sebagian area } \\
\text { padang lamun di perairan. }\end{array}$ \\
\hline
\end{tabular}

Pada stasiun 1 yang letaknya berada di sebelah Utara Pulau Pramuka merupakan daerah perairan yang masih alami jarang aktivitas manusia maupun aktivitas wisata, lingkungan sekitarnya merupakan hutan yang masih terjaga, tidak ada tempat saluran pembuangan limbah cair dan pembuangan sampah di sana, sehingga hal ini membuat lamun yang tumbuh di perairan tersebut memiliki nilai kerapatan dan persentase tertinggi dibandingkan dengan dua stasiun lainnya. Parameter fisika dan kimia yang terukur di stasiun ini juga masih dalam kondisi normal. Hal ini terbukti sesuai dengan pernyataan BTNKpS (2004), dari jenis lamun yang tumbuh di pulau pemukiman, rata-rata kerapatan dan biomassanya lebih kecil dibandingkan oleh pulau yang bukan pemukiman.

Stasiun 2 letaknya berada di sebelah Timur Pulau Pramuka tempat yang digunakan sebagai pemukiman penduduk. Lokasi ini dekat dengan pemukiman penduduk oleh karena itu banyak ditemukan aktivitas antropogenik yang dapat merusak kehidupan lamun di sekitar lokasi ini. Di sekitar stasiun ini ditemukan 2 lokasi tempat pembuangan sampah akhir dari seluruh kumpulan sampah masyarakat yang tinggal di Pulau Pramuka. Tempat pembuangan sampah tersebut letaknya di pinggiran dam mendekati laut, jadi jika sampah padat tersebut didiamkan terlalu lama tidak dibakar dan menumpuk akan terbawa angin ataupun berjatuhan ke laut dan berserakan di laut itulah yang dilihat selama penelitian, jarak dari dam sampai 5 meter ke laut masih terlihat sampah padat menggenang ada pula yang terbenam menutupi tumbuhnya lamun. Sampah padat yang ditemukan seperti plastik, gabus, kaleng bekas kemasan, daun-daun kering dan lainnya. Selain sampah padat ditemukan pula 2 saluran limbah cair yang bermuara ke tempat ini. Hal ini terbukti dari hasil parameter fisika dan kimia pada lokasi ini. Pada stasiun ini nilai $\mathrm{pH} \mathrm{8,2}$ 
dibanding dengan stasiun lain nilai ini lebih tinggi, $\mathrm{pH}$ tersebut tergolong basa, selain itu nilai salinitas yang terukur sangat rendah yaitu $27 \%$ dan nilai TSS paling tinggi terdapat pada lokasi ini. Hal ini sesuai dengan pernyataan Agung (2012) bahwa limbah domestik memiliki karakteristik yang kerap ditemui berupa tingginya kandungan detergen, sabun, nitrogen, fosfor, hidrogen silfida, bahan organik (BOD dan COD), TSS dan nilai $\mathrm{pH}$. Nilai $\mathrm{pH}$ yang tinggi dan salinitas yang rendah ini mungkin karena perairan laut sekitar lokasi terkontaminasi dengan buangan limbah-limbah cair yang dihasilkan dari kegiatan masyarakat sehari-hari seperti mandi, cuci dan tinja. Sampah padat dan limbah cair yang sampai ke laut mempengaruhi nilai TSS di lokasi ini menjadi tinggi, yaitu $18 \mathrm{mg} / \mathrm{l}$ meskipun masih di bawah normal baku mutu TSS untuk kehidupan biota laut, namun jika tidak ditindak lanjuti nilai TSS tersebut bisa saja semakin meningkat seiring dengan meningkatnya buangan limbah sekitar lokasi. Nilai TSS yang tinggi mempengaruhi fotosintesis dari lamun itu sendiri, karena TSS yang tinggi menghalangi cahaya matahari yang masuk ke dalam perairan, apalagi jika sampah padat yang dibuang ke perairan laut tersebut menutupi tempat hidupnya lamun. Berdasarkan hasil penelitian nilai persentase dan kerapatan lamun di lokasi ini paling rendah dibandingkan dengan kedua lokasi lainnya. Hal ini sesuai dengan pernyataan Kisawara (2000), bahwa kerapatan dan persentase penutupan jenis lamun dipengaruhi faktor tempat tumbuh dari lamun tersebut.

Stasiun 3 letaknya berada di sebelah Selatan Pulau Pramuka, lokasi ini biasa digunakan untuk pemukiman dan selain itu juga sebagai tempat wisata sehingga banyak ditemukan resort wisata di sini. Aktivitas manusia pun banyak terdapat di lokasi ini, apalagi ketika musim liburan tiba, wisatawan yang berkunjung bisa memenuhi tempat ini, kegiatan wisata dan aktivitas lainnya dapat berpengaruh langsung kepada biota laut di sekitarnya seperti lamun. Pembangunan sarana dan prasarana seperti resort wisatawan, restoran, serta aktivitas olahraga pantai seperti banana boat, serta kegiatan lainnya yang berada disekitar pantai yang menyebabkan lamun terancam rusak karena terinjak oleh manusia, serta limbah sampah sisa makanan yang langsung dibuang ke laut terdapat di lokasi ini. Terlihat sampah padat menggenangi laut di sekitar lokasi penelitian seperti sampah palstik kemasan, gabus, kaleng, daun-daun lamun dan lainnya mewarnai perairan laut di lokasi penelitian. Di tempat ini juga terdapat saluran limbah cair seperti yang terdapat di stasiun 2, namun jumlahnya hanya satu saluran. Hal tersebut mempengaruhi parameter fisika dan kimia tempat lamun hidup, pada stasiun 3 ini masih di bawah baku mutu namun jumlahnya hampir mendekati batas baku mutu, seperti halnya stasiun 2, stasiun 3 pun tidak jauh berbeda nilai $\mathrm{pH}$ dan TSS cukup besar dengan nilai salinitas yang rendah. Nilai pH 8,0, TSS $12 \mathrm{mg} / \mathrm{l}$. Hal itu disebabkan karena perairan laut sudah tercampur dengan limbahlimbah domestik yang ada di sekitar lokasi.

Pada stasiun 2 dan 3 juga ditemukan adanya penimbunan/reklamasi pantai. Penimbunan/reklamasi pantai itu bertujuan untuk memperluas daratan dan untuk dam lingkar pantai sebagai pemecah ombak. Penimbunan/reklamasi di Pulau Pramuka itu, dimulai pada tahun 2010, dan terus dilakukan dengan luasan sekitar 72.000 meter $2 /$ tahun atau $0,072 \mathrm{~km}^{2} /$ tahun. Itu sudah terjadi di wilayah Barat, Timur dan Selatan Pulau Pramuka, di wilayah Utara baru akan direncanakan reklamasi. Jika dilihat dari data lamun pada Tabel 1, persentase lamun dari tahun 2009 ke tahun 2011 mengalami penurunan yang sangat besar pada stasiun 2 , hal ini membuktikan bahwa penimbunan/ reklamasi pantai dapat menghilangkan sebagian area lamun pada perairan.

\section{KESIMPULAN}

Berdasarkan hasil penelitian mengenai kondisi lamun (seagrass) di Perairan Pulau Pramuka, Kepulauan Seribu, maka dapat disimpulkan bahwa kondisi lamun di Perairan Pulau Pramuka tergolong ke dalam kriteria lamun yang kurang sehat sampai dengan 
miskin lamun, dengan persentase penutupan lamun pada stasiun 1 sebesar $31 \%$ tergolong ke dalam kondisi kurang sehat, stasiun 2 dan 3 dengan persentase $19,4 \%$ dan $20,3 \%$ dan tergolong ke dalam kategori kondisi miskin lamun.

Dari semua parameter kualitas perairan yang terukur, kualitas perairan habitat lamun yang mengalami perubahan yaitu nilai $\mathrm{pH}$ dan TSS yang tinggi namun masih di bawah baku mutu air laut untuk biota laut. Hal itu terjadi pada stasiun 2 dengan nilai TSS $18 \mathrm{mg} / \mathrm{l}$ dan nilai $\mathrm{pH} 8,2$.

Kualitas perairan dipengaruhi secara langsung oleh aktivitas antropogenik yang ditemukan di setiap stasiun pengamatan. Stasiun 1 masih dalam kondisi yang baik bagi pertumbuhan lamun, karena di stasiun ini merupakan daerah yang masih alami jauh dari aktivitas manusia, sedangkan stasiun 2 dan 3 telah mengalami perubahan struktur komunitas lamun karena di stasiun ini ditemukan beberapa aktivitas antropogenik yang mengganggu kehidupan lamun, sebagian besar berasal dari aktivitas manusia seperti pembuangan limbah domestik dan penimbunan/reklamasi pantai. Hal tersebut yang mempengaruhi kualitas perairan habitat lamun sehingga kondisi lamun pada stasiun 2 dan 3 tergolong miskin lamun.

\section{DAFTAR PUSTAKA}

Azkab, MH. 2000. Struktur dan Fungsi Pada Komunitas Lamun. Majalah IImiah Semi Populer Oseana 25(3):9-17

Balai Taman Nasional Kepulauan Seribu (BTNKpS). 2004. Inventarisasi Padang Lamun di Taman Nasional Kepulauan Seribu. Jakarta. 2012. Inventarisasi Padang Lamun di Taman Nasional Kepulauan Seribu. Jakarta.

Bengen DG. 2001. Ekosistem dan Sumberdaya Alam Pesisir dan Laut. Sinopsis. Pusat Kajian Sumberdaya Pesisir dan Lautan. Bogor: IPB.
Dahuri, R. 2001. Pengelolaan Sumber Daya Wilayah Pesisir dan Lautan Secara Terpadu. Jakarta: Pradnya Paramita. - 2003. Keanekaragaman Hayati Laut: Aset Pembangunan Berkelanjutan Indonesia. Jakarta: Gramedia Pustaka Utama.

Effendi H. 2003. Telaah Kualitas Air Bagi Pengeloaan dan Sumberdaya Lingkungan Perairan. Yogyakarta: Kanisius. $258 \mathrm{hlm}$

Hemminga, MA dan Duarte, CM. 2000. Seagrass Ecology. Cambridge: Cambridge University Press.

Hutomo, H. 1997. Padang Lamun Indonesia: Salah Satu Ekosistem Laut Dangkal yang belum banyak dikenal. Jurnal Puslitbang Oseanologi - LIPI. Jakarta, Indonesia.

Kiswara. 2004. Kondisi padang lamun (seagrass) di perairan teluk Banten 19982001. Lembaga Penelitaian Oseanografi, Lembaga IImu Pengetahuan Indonesia. Jakarta. xii $+33 \mathrm{hml}$.

Nontji, A. 2007. Laut Nusantara. Jakarta: Djambatan.

.2010. Saatnya Peduli Padang Lamun. Jakarta: Harian Kompas, 05/01.

Romimohtarto dan Juana. 2001. Biologi Laut: IImu Pengetahuan Biota Laut. Jakarta: LIPI.

Setiadi, Dede. 2010. Dampak Aktivitas Antropogenik Terhadap Kualitas Perairan Habitat Padang Lamun di Kepulauan Spermonde Sulawesi Selatan. Sulawesi: UNHAS.

Supriharyono. 2007. Konservasi Ekosistem Sumberdaya Hayati di Wilayah Pesisir dan Laut Tropis. Yogyakarta: Pustaka Pelajar.

Syakti, Agung Dhamar. 2012. Agen Pencemaran Laut. Bogor: IPB Press.

Terangi (Terumbu Karang Indonesia). 2007. Laporan Pengamatan Terumbu Karang Kepulauan Seribu (2003-2005). Jakarta.

Tomascik, T., A.J. Mah, A. Nontji, \& M.K. Moosa. 1997. The Ecology of the Indonesian Seas. Part Two. Perilus Edition, Singapore: vi + $1388 \mathrm{hlm}$. 